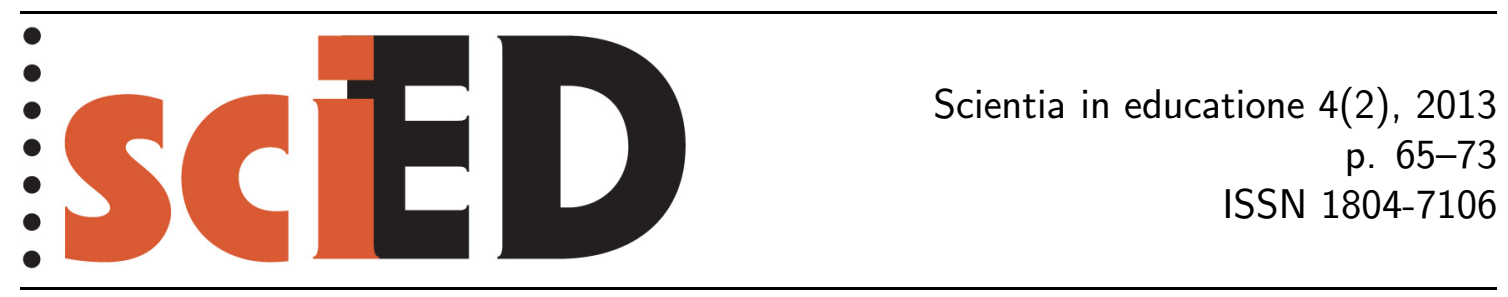

\title{
Aké vedomosti majú slovenskí študenti a učitelia primárneho vzdelávania o pohybe vesmírnych telies?
}

\author{
Klára Velmovská
}

\begin{abstract}
Abstrakt
So základnými vedomostami o vesmíre sa žiaci stretnú na hodinách prírodovedy v 3 . a 4. ročníku a na niekolkých hodinách geografie v 5 . ročníku. Na hodinách fyziky sa s astronómiou stretnú len okrajovo. Dotazníkom sme zistovali úroveň vedomostí o pohyboch vesmírnych telies u vybraných skupín respondentov na Slovensku - navzájom sme ich porovnali a identifikovali niekolko miskoncepcií spojených s touto témou. Po vyhodnotení a štatistickom spracovaní výsledkov dotazníka sme zistili, že úroveň vedomostí študentov učitelstva je porovnatelná s úrovňou vedomostí žiakov základnej školy. Úroveň vedomostí učitelov primárneho vzdelávania z praxe bola síce vyššia ako u študentov učitelstva, ale ani u tejto skupiny celkové priemerné skóre v dotazníku so základnými otázkami o pohyboch vesmírnych telies neprekračuje $60 \%$.
\end{abstract}

Klíčová slova: astronómia, dotazník, primárne vzdelávanie, miskoncepcie.

\section{What Knowledge do Slovak Students and Primary Education Teachers Have about the Movements of Celestial Bodies?}

\begin{abstract}
Students get the basic knowledge about the universe in science classes in years 3 and 4 and in some geography classes in year 5 . In physics classes they get in touch with astronomy; however, only marginally. Using questionnaire we investigated what knowledge of the motion of celestial bodies have selected groups of respondents in Slovakia - we compared these groups and identified the misconceptions connected with this theme. After evaluation and statistical processing of the questionnaire's results we found out, that primary school and university students have comparable level of knowledge about this topic. Although the level of knowledge of primary education teachers surpasses the level of knowledge of university students, the success rate of this group according to questionnaire with basic questions about the motion of celestial bodies does not exceed $60 \%$.
\end{abstract}

Key words: astronomy, questionnaire, primary education, misconceptions. 


\section{INTRODUCTION}

In primary and secondary schools in Slovakia, astronomy is not a separate part of physics classes (ŠPU, 2009a; ŠPU, 2009b). Students get the basic knowledge about the universe in science classes in years 3 and 4 and some geography classes in years 3 and 4 (ك̌PÚ, 2011) as well as some geography classes in year 5 of the primary school (ŠPU, 2010). They learn about astronomy-related topics marginally as part of some physics topics (Hanisko, 2013). It's relatively known fact that some schools implemented astronomy topics into the curricula, and some schools even have separate astronomy-themed courses. Nevertheless, teachers don't have any official materials covering such topics (textbooks, knowledge requirements, workbooks, ....), therefore they need to look for and develop such documents on their own to the extent they consider appropriate. The content of the classes can draw inspiration from the physics textbook for year nine of primary schools (Janovič et al., 2009, p. 65-82) and the science textbook for the FAST program (Demanche, 1995, p. 68-140). Both books apply a historic approach to the explanation of the phenomena in the universe.

To the students, the universe is something mysterious, and they have numerous pre-conceptions and misconceptions in this respect. Let us name some typical misconceptions discovered by a research of students in Italy, where the author believes that the results are generally applicable (Benacchio, 1999):

- "Moon phases are caused by the shadow cast by the Earth.

- Eclipse of the Moon is a special case of the phases of the Moon.

- Moon is a source of light just like the Sun.

- At the same time, different observers can see Moon in different phases.

- There is no gravity 'on' the Moon."

McDaid (n.d.) indicates some common misconceptions about astronomy. We choose several of them:

- "Whither seasons? Seasons are caused by Earth changing its distance from the Sun as it orbits the Sun.

- Dark side of the Moon: The Moon has a "dark" side that is in eternal darkness.

- Far Side= Dark Side: The Moon's dark side is the side we can never see.

- Planets close enough to touch: Movies show three planets hanging in the sky of an alien world.

- Neighboring stars: Getting from one star system to another only takes a few days.

- Ocean tides: Only the Moon causes tides. Nothing else is involved.

- No gravity on the Moon: Because gravity is only on Earth.

- The North Star: It's the brightest star in the sky.

- Moon phases: They're caused by the shadow of Earth. 
- Planets are basically the same: Jupiter's just a giant version of Earth.

- All stars are ours: Stars shine by reflected light from the Sun.

- Lunar phase names: A first quarter moon is $25 \%$ lit up.

- Bright Moon, still shining: The Moon is really reflective.

- Run for your lives! It's an eclipse! Looking at any eclipse is dangerous.

- The lesser light: The Moon can only be seen during the night."

Do students have similar misconceptions also in Slovakia? Based on the survey, we will evaluate the knowledge primary school students, future teachers and primary education teachers in the practice have about the movements of the celestial bodies. We can find research overviews about preconceptions from physics in (Mandíková, Trna, 2011). They present and analyze some misconceptions too as well as misconceptions linked with gravitation and astronomy.

\section{RESEARCH FOCUSED ON IDENTIFICATION OF THE LEVEL OF KNOWLEDGE ABOUT THE MOVEMENTS OF CELESTIAL BODIES}

\section{RESEARCH OBJECTIVES}

1. Identify the level of knowledge of primary school students, future teachers (currently university students) and primary education teachers with respect to the movement of celestial bodies.

2. Compare the level of knowledge of primary school students, future teachers (currently university students) and primary education teachers with respect to the movement of celestial bodies.

\section{RESEARCH QUESTIONS}

1. What level of knowledge about celestial bodies' movement have the primary school students, future teachers (currently university teachers) and primary education teachers?

2. Is the level of knowledge of primary school students, future teachers (currently university students) and primary education teachers about movement of celestial bodies comparable?

\section{RESEARCH HYPOTHESES}

H1: In comparison with primary school students, the level of knowledge of university students about the movements of celestial bodies is higher.

H2: In comparison with university students, the level of knowledge of primary education teachers about the movements of celestial bodies is higher. 


\section{METHODS OF RESEARCH}

To identify the level of knowledge about the movements of celestial bodies we used a criterion-referenced test that included tasks aimed at the phases of the Moon, at the relative movement of the Sun in the sky, and at the constantly changing seasons of the year. The test included 6 tasks that could be, in our opinion, answered by any individual having an average level of education. The questions can be classified as open questions. According to Bloom's taxonomy, searching for answers to questions requires applying learned facts under new circumstances. We have processed and analyzed the collected data in Excel.

\section{Questions:}

1. Complete the approximate shape of the Moon in the sky one week from now if it is full Moon tonight.

2. How should be a room oriented so that the sun shines as long as possible through the window?

3. Why does a leap year have an extra day?

4. Why sun collectors in our country are installed on the roofs at a certain angle rather than in a horizontal or vertical position?

5. Why is it winter in the southern hemisphere when there is summer in our country?

6. Is there a spot on the Earth where the Sun does not go down over the horizon for 24 hours? If it is, where is it?

\section{CharaCteristics OF THE RESEARCH SAMPLE}

We addressed 69 students of a randomly selected primary school (23 students from year 7, 31 students from year 8, and 15 students from year 9), 45 students in year 1 of a graduate program for primary education teachers (Faculty of Education, Constantine the Philosopher University in Nitra), and 12 teachers for ISCED 1 level in the practice (continuing education participants). The primary school (PS) students made the test in March 2012, university (UNI) students and teachers in April/May 2013 .

Tab. 1: Number of respondents

\begin{tabular}{|c|c|c|c|}
\hline Group & PS & UNI & teachers \\
\hline Number & 69 & 45 & 12 \\
\hline
\end{tabular}

\section{Processing AND Interpretation of RESUlts}

The maximum possible score was 12 points - 2 points for each correct answer, 1 point for each partially correct answer, and 0 for each incorrect answer. Tab. 2 shows the frequency of total score by individual groups of respondents.

Tab. 2 can be transformed into Graph 1 showing the spread of the score relative frequency within individual groups. Tab. 3 shows the results after the calculation of the success rate of individual groups in per cent (success rate in per cent $=100 \%$. mean/12). 
Tab. 2: Frequency and relative frequency of total score by individual groups of respondents

\begin{tabular}{|c|r|r|c|}
\hline \multirow{2}{*}{ Score } & \multicolumn{3}{|c|}{ Frequency } \\
\cline { 2 - 4 } & PS & UNI & teachers \\
\hline 0 & 8 & 4 & 0 \\
\hline 1 & 13 & 2 & 0 \\
\hline 2 & 10 & 14 & 0 \\
\hline 3 & 10 & 4 & 0 \\
\hline 4 & 13 & 8 & 3 \\
\hline 5 & 10 & 2 & 3 \\
\hline 6 & 3 & 7 & 2 \\
\hline 7 & 1 & 3 & 3 \\
\hline 8 & 1 & 1 & 0 \\
\hline 9 & 0 & 0 & 0 \\
\hline 10 & 0 & 0 & 1 \\
\hline 11 & 0 & 0 & 0 \\
\hline 12 & 0 & 0 & 0 \\
\hline Total & 69 & 45 & 12 \\
\hline
\end{tabular}

\begin{tabular}{|c|r|r|c|}
\hline \multirow{2}{*}{ Score } & \multicolumn{3}{|c|}{ Relative frequency / \% } \\
\cline { 2 - 4 } & \multicolumn{1}{|c|}{ PS } & \multicolumn{1}{|c|}{ UNI } & teachers \\
\hline 0 & 11.59 & 8.89 & 0.00 \\
\hline 1 & 18.84 & 4.44 & 0.00 \\
\hline 2 & 14.49 & 31.11 & 0.00 \\
\hline 3 & 14.49 & 8.89 & 0.00 \\
\hline 4 & 18.84 & 17.78 & 25.00 \\
\hline 5 & 14.49 & 4.44 & 25.00 \\
\hline 6 & 4.35 & 15.56 & 16.67 \\
\hline 7 & 1.45 & 6.67 & 25.00 \\
\hline 8 & 1.45 & 2.22 & 0.00 \\
\hline 9 & 0.00 & 0.00 & 0.00 \\
\hline 10 & 0.00 & 0.00 & 8.33 \\
\hline 11 & 0.00 & 0.00 & 0.00 \\
\hline 12 & 0.0 & 0.00 & 0.00 \\
\hline Total & 100 & 100 & 100 \\
\hline
\end{tabular}

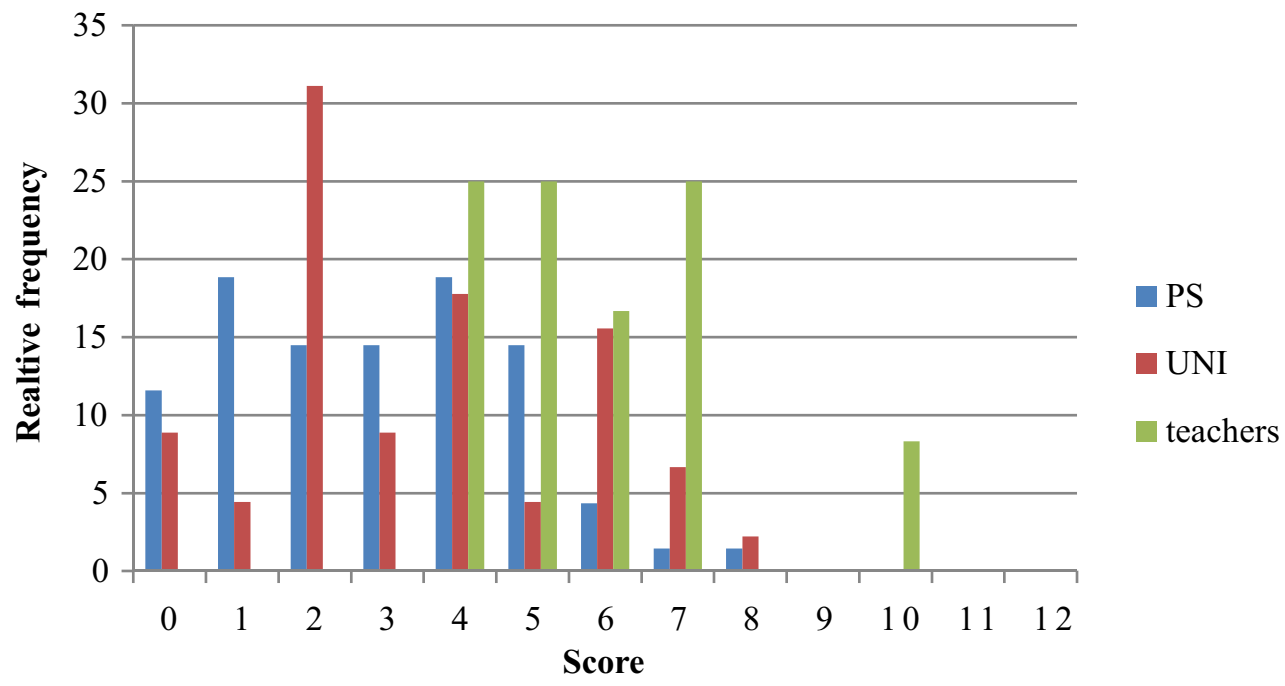

Fig. 1: Relative frequency of score in individual groups

Tab. 3: Success rates of individual groups

\begin{tabular}{|c|c|c|c|}
\hline Group & PS & UNI & teachers \\
\hline Mean & 2.87 & 3.44 & 5.83 \\
\hline Success rate in per cent / \% & 23.91 & 28.70 & 48.61 \\
\hline $95 \%$ confidence limit for mean & $\langle 2.41 ; 3.33\rangle$ & $\langle 2.80 ; 4.09\rangle$ & $\langle 4.72 ; 6.94\rangle$ \\
\hline $\begin{array}{c}95 \% \text { confidence limit } \\
\text { for percentage success rate }\end{array}$ & $\langle 20.05 ; 27.78\rangle$ & $\langle 23.35 ; 34.06\rangle$ & $\langle 39.35 ; 57.87\rangle$ \\
\hline
\end{tabular}

The lowest success rate was recorded for primary school students, the highest for primary education teachers. 
To verify the above hypotheses $\mathrm{H} 1$ and $\mathrm{H} 2$ we analyzed and compared the total score achieved by individual groups. The number of answers within individual groups is shown in Tab. 2.

To verify the $\mathrm{H} 1$ hypothesis, we formulated hypothesis $\mathrm{H}_{01}$ that the mean score of the primary school group equals with the mean score of the university group and then verified this hypothesis. By the F-test we had rejected the hypothesis about the equality of two variances $\left(F=0.82>F_{\text {krit }}=0.64\right)$ and therefore applied the two-tailed t-test for various variances (Tab. 4$)$.

Tab. 4: Statistical comparison of the primary school group's score with the score of university group

\begin{tabular}{|l|c|c|}
\hline t-Test: Two-Sample Assuming Unequal Variances \\
\hline & PS & UNI \\
\hline Mean & 2.87 & 3.44 \\
\hline Variance & 3.73 & 4.57 \\
\hline Observations & 69 & 45 \\
\hline Hypothesized Mean Difference & 0 & \\
\hline df (degrees of freedom) & 87 & \\
\hline t Statistic & -1.46 & \\
\hline$P(T<=t)$ two-tail & 0.15 & \\
\hline t Critical two-tail & 1.99 & \\
\hline
\end{tabular}

The calculated absolute value of $t(-1.46)$ is below the critical value (1.99); therefore we do not reject the $\mathrm{H}_{01}$ hypothesis about the equality of the mean rating. The above facts disprove the $\mathrm{H} 1$ hypothesis.

When exploring the validity of the $\mathrm{H} 2$ hypothesis, we used the $\mathrm{H}_{02}$ null hypothesis about the equality of the mean score of teachers and the mean score of students. We had not rejected the equality of two variances hypothesis by the F-test $\left(F=1.49<F_{\text {krit }}=2.52\right)$; therefore we applied the one-tailed t-test for various variances (Tab. 5).

Tab. 5: Statistical comparison of score for the university and teachers groups

\begin{tabular}{|l|c|c|}
\hline \multicolumn{3}{|c|}{ t-Test: Two-Sample Assuming Equal Variances } \\
\hline & UNI & teachers \\
\hline Mean & 3.44 & 5.83 \\
\hline Variance & 4.57 & 3.06 \\
\hline Observations & 45 & 12 \\
\hline Pooled Variance & 4.27 & \\
\hline Hypothesized Mean Difference & 0 & \\
\hline df (degrees of freedom) & 55 & \\
\hline t Statistic & -3.56 & \\
\hline$P(T<=t)$ one-tail & 0.0004 & \\
\hline t Critical one-tail & 1.67 & \\
\hline
\end{tabular}

The calculated absolute value of $t(-3.56)$ exceeds the critical value (1.67), thus we reject the $\mathrm{H}_{02}$ hypothesis and adopt an alternative hypothesis about the existence of a difference between the mean score of both groups. Therefore we also accept 
the H2 hypothesis that level of knowledge of primary education teachers exceeds the level of knowledge of university students.

\section{DisCUSSION ABOUT THE OUTCOME OF THE RESEARCH}

The question addressed by the research was identifying the level of knowledge of primary school students, future teachers (currently university students) and primary education teachers about the movements of celestial bodies. The success rate (expressed in per cent) of primary school students and university students is relatively low - it did not even reach $35 \%$ (Tab. 3). We expected a higher success rate as the test included question of which we believe that the right answer should be given any average primary school graduate. The success rate of primary education teachers is in the range of 39-58 \%. The number of respondents in this group was relatively low (12) and this group was formed by teachers, which passed continuing education from mathematics and they acceded possibility to set about their knowledge from primary science. For us, it means that these teachers are interested in primary science education, they are not ordinary teachers. We assume that success of the group of respondents was influenced by this fact, thus it would pay out repeating the research with a higher number of ordinary primary teachers.

The analysis of the answers given by the respondents also reveals some interesting facts. As in the first question some respondents drew the Moon as a circle with a missing circular cut-out we believe this being a misconception based on incorrect understanding of the phases of the Moon caused by the shade cast by the Earth.

Some teachers answered question No. 2 by responding: "We don't teach this". Many primary school and university students answered by saying: "I don't know", despite the fact that one method for determining the orientation is by using the position of shadow exactly at noon when the Sun is in the south. And this method is already mentioned in science classes in years 1-4 of the primary school.

Deficiencies in causalities were also revealed. Some respondents answered question No. 3 by saying: "A leap year does have an extra day because there are 29 days in February." Only one respondent from the university group and one teacher brought the leap year in connection with the Earth's circulation around the Sun. The same applies to question No. 5 in which we asked why it is winter on the southern hemisphere when we have summer; some respondents answered by saying: "Because of the seasons of the year." We also saw such answers (given not only of primary school students) as this one: "Because the Sun rotates around the Earth"; "Because when we have the day it is night there." The majority of partially correct answers were about the distance between the Earth and the Sun or whether the northern hemisphere is closer to the Sun and is therefore warmer than the southern hemisphere. We consider this a misconception. Only one primary school student and one university student mentioned the angle of the sunrays in the answer.

Question No. 4 has the highest success rate. Here we considered sufficient the answer, that the sun collectors are installed under a certain angle to the roof so that they catch more sunrays.

Movement of celestial bodies was totally misunderstood by one respondent who provided the following answer to question No. 6: "The Sun does not go down for 24 hours in America, e.g. in California, where it is always hot."

Upon the completion of the statistical evaluation we can say the H1 hypothesis, i.e. if compared with primary school students, university students have higher level of knowledge about the movement of celestial bodies, was not proven. We identified 
that both primary school and university students have comparable level of knowledge about this topic. This means that a primary school student knows as much about the movement of celestial bodies as a future primary education teacher approximately 1 year before the practice.

$\mathrm{H} 2$ hypothesis was statistically proven, which means that the level of knowledge of teachers in practice (continuing education participants) is higher than the level of knowledge of future primary education teachers. A look at the mean score of teachers (Mean value in Tab. 3) shows that it is 5.83 , i.e. the success rate is approximately than $50 \%$. Nevertheless, we expected that teachers in practice will cope with the "movement of celestial bodies" topic not only at the level of memory, but also on a higher level.

\section{Conclusion}

Students observe changes of the moon in the sky, experience the changing seasons of the year, but cannot adequately explain what they see and experience. They have their own ideas that are not always the right ones.

Based on a research aimed at the knowledge primary school students and university students (future primary education teachers) and teachers of students in years 1-4 have about the movements of celestial bodies, we can say that the level of knowledge of all respondent groups is low. We also compared the knowledge individual respondent groups have about the celestial bodies movements and we found that the level of knowledge of primary school students is comparable with the level of knowledge of the university students. In terms of primary education, the level of knowledge of teachers in practice exceeds the level of knowledge of the future teachers, but we do not consider it sufficient as the total success rate was less than $50 \%$ in criterion-referenced test. Similar conclusion about Brazilian teachers was outlined in study elaborated by research group centered around Colombo (Colombo et al, 2010): "Brazilian teachers of primary and low secondary schools usually have a background in biology or pedagogy but not in science in general."

Students can be taught about the Earth as part of the universe in several ways included in the curriculum: As part of separate course or on physics classes; or include individual astronomy topics into the natural science-aimed courses (Pudivitr, 2004). However, the prerequisite are sufficiently competent teachers. And our research shows that it is not the case. It should be taken into consideration whether future primary education teachers should not have, as part of the natural science lessons didactics, have at least some physics lessons (including astronomy) lectured by a physics specialist.

\section{BIBLIOGRAPHY}

BENACCHIO, L. The Importance of the Moon in Teaching Astronomy at the Primary School. Earth, Moon, and Planets, 1999, vol. 85-86, no. 0, p. 51-60.

COLOMBO, P. D., AROCA, S. C., SILVA, C. C. Daytime School Guided Visits to Astronomical Observatory in Brazil. Astronomy Education Review, 2010, vol. 9, no. 1. [online]. The American Astronomical Society, 2010. [retrieved 30-05-2013]. Available at: 〈http://goo.gl/hdNeY $\rangle$ 
DEMANCHE, E. L., KYSELKA, W., POTTENGER III, F. M., YOUNG, D. B. Prírodoveda. FAST 3. Zmeny a čas. Bratislava : ŠPÚ, 1995, $236 \mathrm{s.}$

HANISKO, P. Vyučovanie astronómie na 2. stupni základných škôl v Slovenskej republike. Obzory matematiky, fyziky a informatiky, 2013, vol. 42, no. 2, p. 51-58.

JANOVIČ, J., CHALUPKOVÁ, A., LAPITKOVÁ, V. Fyzika pre 9. ročník základných škôl. Bratislava : SPN, 2000.

MANDÍKOVÁ, D., TRNA, J. Žákovské prekoncepce ve výuce fyziky. Brno : Paido, 2011, $245 \mathrm{~s}$.

McDAID, L. 44 Common Misconceptions About Astronomy. [online], SCC Physics Department, [cit. 2013-13-09], Available at:〈http://goo.gl/jR458o〉

PUDIVÍTR, P. Jak vyučovat astronomii? Matematika, fyzika, informatika, 2004, vol. 13 , no. 6 , p. $352-357$.

ŠPÚ (Štátny pedagogický ústav). Štátny vzdelávací program: Fyzika - Príloha ISCED 2 [online]. Bratislava : ŠÚ, 2009a [retrieved 30-05-2013]. Available at: 〈http://goo.gl/03Avn〉

ŠPÚ (Štátny pedagogický ústav). Štátny vzdelávací program: Fyzika - Príloha ISCED $3 A$ [online]. Bratislava : ŠPÚ, 2009b [retrieved 30-05-2013]. Available at: 〈http://goo.gl/uRoSo〉

ŠPÚ (Štátny pedagogický ústav). Státny vzdelávací program: Geografia - Príloha ISCED 2 [online]. Bratislava : ŚPU, 2010 [retrieved 30-05-2013]. Available at: $\langle$ http://goo.gl/rc0nZ〉

ŠPÚ (Štátny pedagogický ústav). Śtátny vzdelávací program: Prírodoveda - Príloha ISCED 1 [online]. Bratislava : ŠPÚ, 2011 [retrieved 30-05-2013]. Available:

$\langle$ http://goo.gl/uzlWb〉

\section{ACKNOWLEDGEMENT}

This paper was supported by the grant of the project KEGA 130UK-4/2013 "Podpora kvality vyučovania tvorbou materiálov prepojených na učebnice fyziky" (Supporting the quality of education by creation of materials connected with physics textbooks). The author would like to thank Viera Lapitková, Ján Pišút and Miroslav Šedivý for valuable comments and discussions and to Lukáš Bartošovič for improvement of the language.

Klára Velmovská - E-mail: Klara.Velmovska@fmph.uniba.sk Univerzita Komenského v Bratislave, Fakulta matematiky, fyziky a informatiky Katedra teoretickej fyziky a didaktiky fyziky, Slovak Republic 